\title{
A PCR Method That Can Be Further Developed into PCR-RFLP Assay for Eight Animal Species Identification
}

\author{
Feng Guan $(D)$, Yu-Ting Jin, Jin Zhao, Ai-Chun Xu, and Yuan-Yuan Luo \\ College of Life Sciences, China Jiliang University, Hangzhou 310018, China \\ Correspondence should be addressed to Yuan-Yuan Luo; yyluo@cjlu.edu.cn
}

Received 31 May 2017; Accepted 23 October 2017; Published 5 February 2018

Academic Editor: Antony C. Calokerinos

Copyright (c) 2018 Feng Guan et al. This is an open access article distributed under the Creative Commons Attribution License, which permits unrestricted use, distribution, and reproduction in any medium, provided the original work is properly cited.

\begin{abstract}
There are many PCR-based methods for animal species identification; however, their detection numbers are limited or could not identify unknown species. We set out to solve this problem by developing a universal primer PCR assay for simultaneous identification of eight animal species, including goat, sheep, deer, buffalo, cattle, yak, pig, and camel. In this assay, the variable lengths of mitochondrial DNA were amplified using a pair of universal primers. PCR amplifications yielded $760 \mathrm{bp}, 737 \mathrm{bp}$, 537 bp, 486 bp, 481 bp, 464 bp, 429 bp, and 359 bp length fragments for goat, sheep, deer, buffalo, cattle, yak, pig, and camel, respectively. This primer pair had no cross-reaction with other common domestic animals and fish. The limit of detection varied from 0.01 to $0.05 \mathrm{ng}$ of genomic DNA for eight animal species in a $20 \mu \mathrm{l}$ PCR mixture. Each PCR product could be further digested into fragments with variable sizes and qualitative analysis by $S s p$ I restriction enzyme. This developed PCR-RFLP assay was sufficient to distinguish all targeted species. Compared with the previous published related methods, this approach is simple, with high throughput, fast processing rates, and more cost-effective for routine identification of meat in foodstuffs.
\end{abstract}

\section{Introduction}

The consumption of meat and meat products is increasing each year in the world. On the other hand, food authenticity issues in the form of adulteration and improper description have existed for as long as food has been offered for sale. In China, "hang a sheep head, sell vinegar" is a widely known proverb. However, meat adulteration affects food safety, quality, and many other respects, becoming a public focus recently. Since the 1980s, many immunological and molecular methods for species identification in food products have been developed [1-8]. Concomitant with advances in large-scale integrated molecular technology, DNA analysis methods have been in rapid development. Many assays based on DNA analysis, especially PCR-based methods, have been developed for species identification in foodstuffs. Though each of these methods has its own advantages and disadvantages, the number of species identified in a single PCR was limited to 4-5 [9]. Compared with other PCR methods, the combination of universal primer PCR and restriction fragment length polymorphism (RFLP) assays has advantages of increased simplicity, specificity, and sensitivity and has been used in many meat identification practices [10-17]. On the other hand, a few modified PCR assays combining universal primer with specific primer or RFLP had been developed [18, 19]; these methods increased efficiency and versatility. Furthermore, PCR-RFLP had additional advantages over multiplex PCR and species-specific PCR, such as the ability to detect a larger number of animal species and differentiate between closed animal species.

With the development of Western China, more and more local meat products of mutton, beef, yak, deer, and camel have been sold to all parts of the country. There have been a few analytical methods for the identification of yak [20,21], deer [17], buffalo [22, 23], and camel [24] meat in food products, but to our knowledge, there is no one method for simultaneously identifying two and more animal species, for goat, sheep, buffalo, cattle, yak, deer, and camel. Furthermore, pork is popular with Chinese people, but Muslim populations are widely distributed in China; all the meat products from pork source are forbidden in halal foods. In this regard, precise identification of meat origin has become a vital element in food quality control procedures. Thus, the development of reliable, simple, and sensitive analytical 
methods for evaluating meat authenticity is of critical importance.

In recent years, universal primer PCRs have been used and further developed for animal species identification combination with other DNA analysis methods [19, 25-29], which had many advantages over common and even realtime PCR assays. In this study, a new pair of universal primers was designed and a species identification assay has been developed using the variable size fragments, and this assay can be further developed into PCR-RFLP assay, which showed potential as a tool for cost-effective, rapid, specific, and sensitive detection of goat, sheep, buffalo, cattle, yak, deer, pig, and camel simultaneously.

\section{Materials and Methods}

2.1. Samples Collection and DNA Extraction. The samples of known species origins including goat (Capra aegagrus hircus), sheep (Ovis aries), deer (Cervus axis), buffalo (Bovinae), cattle (Bos primigenius), yak (Bos mutus grunniens), pig (Sus scrofa), camel (Pilus cameli), horse (Equus caballus), donkey (Equus asinus), rabbit (Oryctolagus cuniculus), chicken (Gallus gallus), duck (Anas platyrhynchos), rat (Rattus norvegicus), dog (Canis lupus familiaris), frog (Rana catesbiana), and fish (Carassius auratus) were collected from a slaughterhouse and experimental animal center in Hangzhou, China, and were stored at $-20^{\circ} \mathrm{C}$ in our laboratory. In addition, fifteen commercial meat product samples were purchased to assess this developed method in practice; the ingredients were labeled as deer, yak, camel, beef, and mutton, respectively.

Genomic DNA was extracted from meat samples using an Animal Tissue DNA Extraction Kit (Takara) according to supplied instructions. Following DNA extraction, the purity and concentration of all the DNA samples were confirmed using a UV-Vis spectrophotometer (NanoDrop 2000, Thermo). DNA samples were diluted to a final concentration of $10 \mathrm{ng} / \mu \mathrm{l}$ and stored at $4^{\circ} \mathrm{C}$ for next use.

2.2. Universal Primers and PCR Amplification. The mitochondrial DNA (mtDNA) sequences of all the above animals were retrieved from the NCBI database and were aligned using ClustalW sequence alignment tool to select the congenerous conserved regions. Two regions were selected as primer design areas, and a pair of universal primers was designed to amplify variable length mtDNA sequences from genomic DNA of yak, deer, goat, sheep, pig, camel, cattle, and buffalo but no other animals. There were several insertion-deletion polymorphisms in the amplified sequences, which, in theory, could yield different length fragments for each animal. The primer sequences are as follows: forward primer $\left(5^{\prime}\right.$-CCTCCCTAAGACTCAGGGAA $\left.-3^{\prime}\right)$ and reverse primer $\left(5^{\prime}\right.$-AGCGGGTTGCTGGTTTCACG- $\left.3^{\prime}\right)$. The designed primers were also screened for unique specificity to check cross-species binding with other animal or plant species using the online BLAST local alignment tool in the NCBI database.

PCR amplifications were carried out using a MJ-200 thermal cycler in a total of $20 \mu \mathrm{l}$ mixture containing $2.0 \mu \mathrm{l}$ 10x PCR buffer, $1.2 \mu \mathrm{l}$ of dNTP mixture $(25 \mathrm{mM}), 1.6 \mu \mathrm{l}$ $\mathrm{MgCL}_{2}(25 \mathrm{mM}), 1 \mathrm{U}$ of Taq polymerase, $2 \mu \mathrm{l}$ each of universal primers $(10 \mathrm{mM})$, and $3 \mu \mathrm{l}$ DNA template (about $30 \mathrm{ng}$ ). The PCR conditions consisted of preheating at $94^{\circ} \mathrm{C}$ for $5 \mathrm{~min}$, followed by 30 cycles of denaturation at $94^{\circ} \mathrm{C}$ for $30 \mathrm{~s}$, annealing at $61^{\circ} \mathrm{C}$ for $30 \mathrm{~s}$, and extension at $72^{\circ} \mathrm{C}$ for $30 \mathrm{~s}$. Then final extension was done at $72^{\circ} \mathrm{C}$ for $5 \mathrm{~min}$. The $5.0 \mu \mathrm{l}$ PCR product obtained was analyzed on $2 \%$ agarose gel in $1 \mathrm{x}$ TAE buffer stained with $4 \mathrm{~S}$ Red as a visualizing agent and run for $40 \mathrm{~min}$ at $90 \mathrm{~V}$. A known DNA ladder Marker C (Shanghai Sangon Biotech) was electrophoresed simultaneously in order to assess the size of the amplification product.

2.3. Restriction Fragment Length Polymorphism (RFLP) Analysis. To further discriminate between targeted animals, expected nucleotide sequences were restriction mapped with the Mapdraw program of DNASTAR (NY, USA). After testing, one restriction enzyme SspI (TakaRa) was selected to digest the PCR products in separate reactions. Briefly, $5 \mu \mathrm{l}$ of the PCR product and $2 \mu \mathrm{l}$ of the restriction enzyme were prepared by mixing $2 \mu \mathrm{l}$ of $10 \mathrm{x}$ buffer, and sterile free water was added for a total volume of $20 \mu \mathrm{l}$. The tubes were incubated at $37^{\circ} \mathrm{C}$ for approximately $4 \mathrm{~h}$. The digested PCR products were then separated on $2.5 \%$ agarose gel.

2.4. PCR Products Sequencing and Commercial Samples Detection. To further validate this assay, each of the PCR products was purified and then sequenced in Hangzhou Qingke Biotechnology Company and then were analyzed using the BLAST local alignment tool. Fifteen commercial samples were screened using this developed assay, and each of the PCR products obtained was extracted and purified separately and then digested by the restriction enzyme SspI.

\section{Results and Discussions}

3.1. DNA Extraction and PCR Amplifications. In the present study, all the genomic DNA samples were measured. The spectrophotometric assessment results showed that concentrations varied between 20 and $200 \mathrm{ng} / \mu \mathrm{l}$, and the purity $\left(\mathrm{A}_{260} / \mathrm{A}_{280}=1.72-1.96\right)$ was suitable for PCR amplification. The universal primer pair generated $760 \mathrm{bp}, 737 \mathrm{bp}, 537 \mathrm{bp}$, 486 bp, 481 bp, 464 bp, 429 bp, and 359 bp length fragments from goat, sheep, deer, buffalo, cattle, yak, pig, and camel DNA templates, respectively (Figure 1).

3.2. PCR Specificity and Sensitivity. The specificity of primers was checked against the extracted DNA samples from common animals, which included dog, chicken, horse, rat, donkey, rabbit, duck, frog, and fish. The specificity test results showed that no cross amplification was detected. The sensitivity was tested using serially diluted DNA samples from goat, sheep, deer, buffalo, cattle, yak, pig, and camel, and until the PCR products could not be visualized on $2.0 \%$ agarose gel. DNA band patterns (Figure 2) indicated that the detection limit of DNA from pigs was even at $0.001 \mathrm{ng}$, and the minimum detection levels of goat, sheep, deer, buffalo, 


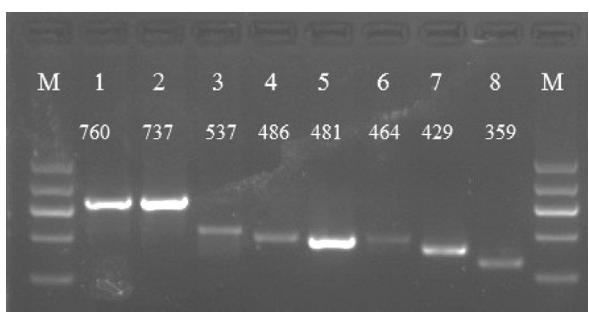

FIGURE 1: PCR amplification results for eight animal species. Lanes 1-8 represent goat, sheep, deer, buffalo, cattle, yak, pig, and camel, respectively. Lane M represents DNA marker; the lengths of different PCR products were noted above the band.

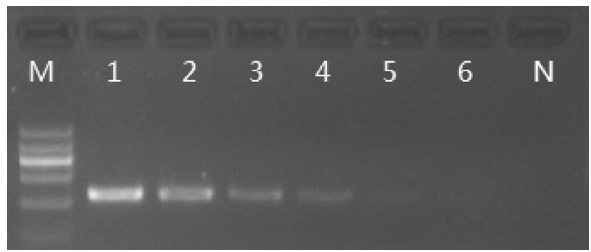

Figure 2: Sensitivity test for pig DNA. Lanes 1-6 represent the PCR products with serial dilution of pig DNA template. The content of pig DNA was $30.0,10.0,1.0,0.1,0.01$, and $0.001 \mathrm{ng}$. Lane $\mathrm{N}$ was negative control.

cattle, yak, and camel DNA templates were between 0.01 and $0.05 \mathrm{ng}$.

3.3. PCR-RFLP Analysis and Sequencing. Each of the PCR products yielded different patterns for eight animal species after SspI restriction enzyme digestion. The PCR products yielded $291 \mathrm{bp}, 192 \mathrm{bp}, 160 \mathrm{bp}$, and $118 \mathrm{bp}$ for goat; $300 \mathrm{bp}$, $213 \mathrm{bp}$, and $75 \mathrm{bp}$ for sheep; $391 \mathrm{bp}$ and $146 \mathrm{bp}$ for deer; $303 \mathrm{bp}$ and $178 \mathrm{bp}$ for cattle; $214 \mathrm{bp}, 178 \mathrm{bp}$, and $73 \mathrm{bp}$ for yak; and $300 \mathrm{bp}$ and $129 \mathrm{bp}$ for pig. However, the PCR products from buffalo and camel DNA could not be cleaved by SspI; thus, the PCR products were always $486 \mathrm{bp}$ and $359 \mathrm{bp}$, respectively. The PCR product digestion patterns are shown in Figure 3. Unique restriction pattern of SspI for each species was found to satisfactorily differentiate between all eight animal species.

To confirm the developed method, each of the PCR products was purified and sequenced. The sequencing results indicated that the sizes and sequences of all the PCR products corresponded exactly to that of the expected amplicons. The similarity parameters were as high as $100 \%$ in accordance with the GenBank database. One exception was buffalo (98.2\%). This difference was caused by two single nucleotide polymorphic loci detected in the referenced sequence of buffalo compared to GenBank Accession no. AY702618. The sequencing results were fully in accordance with the expected amplicons, which indicates that this developed assay had a higher specificity.

3.4. Commercial Samples Detection. The fifteen commercial meat products were detected using this developed assay, two

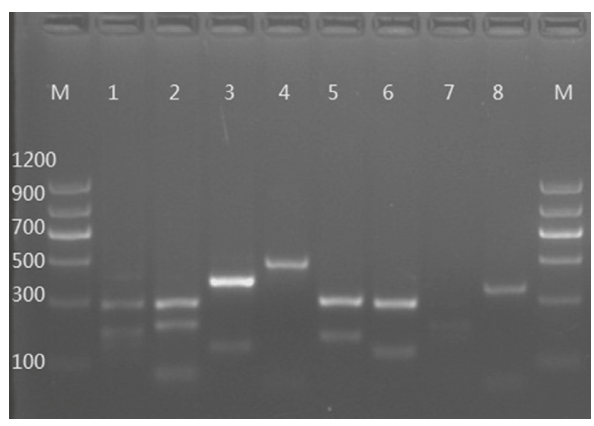

Figure 3: The PCR-RFLP result for eight target animals. Lane M represents DNA marker; lanes 1-8 represent goat, sheep, deer, buffalo, cattle, yak, pig, and camel, respectively.

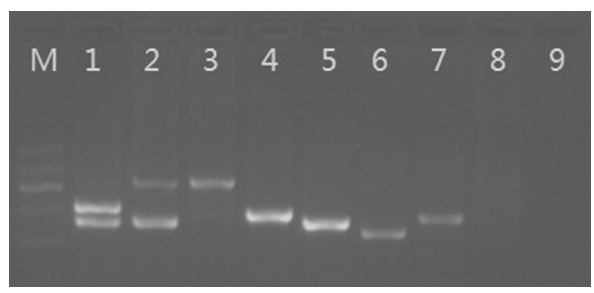

FIgURE 4: Identification results of commercial meat samples. Samples in lanes 1-7 were labeled as deer, mutton, mutton, beef, pork, camel, and yak meat. Lane 8 was soybean DNA, and lane 9 was negative control. But, the samples in lanes 1 and 2 contained pork.

animal ingredients were found in two of the fifteen samples, while other samples had only one ingredient (Figure 4). The two samples were labeled as deer meat and mutton, respectively. Judging from the electrophoretic profiles, these two meat products were adulterated with pork. To confirm this finding, all the electrophoretic bands were extracted and sequenced. Sequencing results confirmed that the two samples contained pork ingredients. The other thirteen samples contained only one meat ingredient and were consistent with the labeling meat species.

With the development of economy, meat products become a daily food for consumption. Furthermore, yak, camel, and deer meats are new popular meat products in the Chinese market, especially as leisure foods. The price of these meat products is higher than that of common meat products such as beef and pork. On the other hand, the rising price and decreasing availability of high-quality meat drive some meat producers to misrepresent and/or adulterate meat and meat products. In fact, food adulteration has been around for a long time. The most common economic fraudulence widely spread in meat industry is adulteration or substitution of costlier meat with cheaper or inferior meat. Preventing meat adulteration in foods is important for economic, religious, and health reasons. In addition, identification of the species origin in processed meat products is an important task in food hygiene, food codex, food control, and veterinary forensic medicine.

In order to protect consumers from fraud and adulteration, many meat and/or animal species identification methods have been developed to date. DNA assays have 
become common methods in practice because they have many advantages over other analyses. The stability of mtDNA is higher than that of genomic DNA and it is distributed in all the tissues. Therefore, mtDNA sequences are preferential for DNA barcoding in species identification $[9,30-37]$. It is clear that PCR assay is a preferred technique based on DNA analysis for meat species identification to date. PCR and its derived techniques have been widely used for meat authentication, which included DNA hybridization, species-specific PCR, multiplex PCR, PCR-RFLP, PCRSSCP, and PCR sequencing $[2,31,38,39]$. Among these techniques, PCR-RFLP is considered as a highly discriminatory, reliable, and reproducibility method. Furthermore, the advantage of mitochondrial DNA-based PCR-RFLP analysis derives from the fact that there are many mitochondria per cell and many mitochondrial DNA molecules within each mitochondrion, making mtDNA a naturally amplified source of genetic variation [10, 14, 24, 32, 40, 41].

In the past few years, PCR-RFLP assays had been used to identify food animal species targeting CytB gene [14, 17, 42] and $12 \mathrm{~S}$ rRNA gene $[16,43]$. Among these assays, the same length fragments were amplified from two or more animals in the PCR procedure, then PCR products were digested using one or more restriction enzymes to yield different patterns [14, 15]. Partis et al. [34] developed a PCR-RFLP method for the detection of 22 animal species, but this method was unsuitable for analyzing meat mixtures. Several similar multiplex species identification assays had been reported. For example, Wang et al. [32] reported a terminal restriction fragment length polymorphism (T-RFLP) method for the identification of 12 animal species by targeting the $12 \mathrm{~S}$ rRNA gene, but it required two restriction enzymes, double-fluorescently labeled primers and capillary electrophoresis. Hanapi et al. [44] reported a common primer multiplex PCR (CP-M-PCR) for the identification of pig, ruminant, avian, and rabbit meat, but this method could not distinguish closely related species, such as buffalo and cattle, and sheep and goat. There have been other several reported related methods based on PCR analysis, but these methods were often not suitable for mixture of food products, as the process was time consuming, inadequate, and expensive.

In the present study, a modified PCR assay was developed using universal primers for simultaneous identification of goat, sheep, deer, buffalo, cattle, yak, pig, and camel. Also, this assay could be further developed into RFLP method; the fragments of different lengths produced from PCR products could be identifying the animal species. This method can detect any targeting individual species within a meat mixture, which had better discrimination and specificity than many other multiple PCR methods.

This developed PCR-RFLP assay was a simple and rapid technology for identifying multiple species. This method did not require expensive equipment, and the optimization procedure was simple in comparison with multiplex PCR, real-time PCR, and other technologies that are used for the detection of two or more animal species. Interestingly, this method could identify individual species within a meat mixture by separating different size PCR products.
This method was developed based on conventional PCR platform and required a common PCR thermal cycler, so it could be carried out in most laboratories. Furthermore, the developed PCR had no cross-reaction with DNA samples from common meats, such as duck, chicken, rat, frog, fish, donkey, and horse, and the PCR system had a high sensitivity at a minimum level of $0.001 \mathrm{ng}$ of DNA. In general, the detection sensitivity for animal species such as poultry, ruminant, and pig using common PCR and real-time PCR was up to $0.1-1 \%$ of the ingredients and was also able to detect common meat species down to 0.15-0.01 ng of DNA $[19,45,46]$. So, it seems that the sensitivity is even higher than that of real-time PCR targeting for genomic DNA. This high sensitivity was probably because mtDNA was a multiple copy gene in each cell, and there was an increased probability of survival under different processing conditions. These advantages ensured that amplification was successful even in certain samples containing small amounts of DNA [47]. Although this developed PCR-RFLP had advantages over conventional PCR and multiplex PCR in some respects, it could not well satisfy the needs for meat products supervision in practice. Instead, this process could be combined with other species identification methods to get a better result in practice. For example, this method could combine with other species-specific primers to establish a multiplex PCR or combined with direct PCR to improve the speed [48, 49]. In fact, the choice of an appropriate method for species identification is decided by multiple considerations, such as sensitivity, specificity, accuracy, discriminatory ability, reproducibility, cost, speed, availability of equipment, and availability of suitably trained staff. The developed method provides more choices for animal identification, especially for meat food supervision.

\section{Conclusion}

In conclusion, a pair of universal primers for amplifying variable length fragments in eight animal species was designed and a PCR assay was developed, which could be further developed into PCR-RFLP. This developed method can be used to identify eight animal species. This method was specific, sensitive, and reliable in the simultaneous identification of goat, sheep, deer, buffalo, cattle, yak, pig, and camel. This proposed method was relatively simple and rapid, does not require expensive equipment, and could be performed in most laboratories. It is a practical approach for routine analysis to determine fraudulent and/or mislabeled substitution in meat products.

\section{Conflicts of Interest}

The authors have declared that no conflicts of interest exist.

\section{Acknowledgments}

The authors would like to thank all the people for collecting the samples and they also gratefully acknowledge financial support from the National Natural Science Foundation of China (Nos. 31672394 and 31360540), the Science and 
Technology Department of Zhejiang for public welfare Technology Application Research (2017C32081), and the Major State Basic Research Development Program of China (2017YFD0501904).

\section{References}

[1] M. Safdar and Y. Junejo, "The development of a hexaplexconventional PCR for identification of six animal and plant species in foodstuffs," Food Chemistry, vol. 192, pp. 745-749, 2016.

[2] A. Kumar, R. R. Kumar, B. D. Sharma, P. Gokulakrishnan, S. K. Mendiratta, and D. Sharma, "Identification of species origin of meat and meat products on the DNA basis: a review," Critical Reviews in Food Science and Nutrition, vol. 55, no. 10, pp. 1340-1351, 2015.

[3] B. Hou, X. Meng, L. Zhang, J. Guo, S. Li, and H. Jin, "Development of a sensitive and specific multiplex PCR method for the simultaneous detection of chicken, duck and goose DNA in meat products," Meat Science, vol. 101, pp. 90-94, 2015.

[4] Z. M. Li, L. J. Zhao, Y. F. Wang, and H.-W. Zhang, "Progress of molecular identification techniques used in meat and meat products," Journal of Food Safety and Quality, vol. 6, no. 2, pp. 405-409, 2015.

[5] A. Doosti, P Ghasemi Dehkordi, and E. Rahimi, "Molecular assay to fraud identification of meat products," Journal of Food Science and Technology, vol. 51, no. 1, pp. 148-152, 2014.

[6] A. Vlachos, I. S. Arvanitoyannis, and P. Tserkezou, "An updated review of meat authenticity methods and applications," Critical Reviews in Food Science and Nutrition, vol. 56, no. 7, pp. 1061-1096, 2013.

[7] A. Iwobi, I. Huber, and U. Busch, "The application of PCR-based methods in food control agencies-a review," in Polymerase Chain Reaction, pp. 173-194, Bavarian Health and Food Safety Authority, Oberschleissheim, Germany, 2012.

[8] R. Rodríguez-Ramírez, A. F. González-Córdova, and B. Vallejo-Cordoba, "Review: authentication and traceability of foods from animal origin by polymerase chain reactionbased capillary electrophoresis," Analytica Chimica Acta, vol. 685 , no. 2, pp. 120-126, 2011.

[9] M. T. Bottero and A. Dalmasso, "Animal species identification in food products: evolution of biomolecular methods," Veterinary Journal, vol. 190, no. 1, pp. 34-38, 2011.

[10] Y. Erwanto, M. Z. Abidin, E. Y. Sugiyono, and A. Rohman, "Identification of pork contamination in meatballs of Indonesia local market using polymerase chain reaction-restriction fragment length polymorphism (PCR-RFLP) analysis," AsianAustralasian Journal of Animal Sciences, vol. 27, no. 10, pp. 1487-1492, 2014.

[11] X. Huang, X. Zhou, Q. Lin, W. Fang, and X. Chen, "PCRRFLP technique for species identification of molted feathers in six species of co-occurring Ardeids," Conservation Genetics Resources, vol. 5, no. 3, pp. 817-819, 2013.

[12] D. Maede, "A strategy for molecular species detection in meat and meat products by PCR-RFLP and DNA sequencing using mitochondrial and chromosomal genetic sequences," European Food Research and Technology, vol. 224, no. 2, pp. 209-217, 2006.

[13] Y.-L. Sun and C. S. Lin, "Establishment and application of a fluorescent polymerase chain reaction-restriction fragment length polymorphism (PCR-RFLP) method for identifying porcine, caprine, and bovine meats," Journal of Agricultural and Food Chemistry, vol. 51, no. 7, pp. 1771-1776, 2003.
[14] D. Kumar, S. P. Singh, N. S. Karabasanavar, R. Singh, and V. Umapathi, "Authentication of beef, carabeef, chevon, mutton and pork by a PCR-RFLP assay of mitochondrial cytb gene," Journal of Food Science and Technology, vol. 51, no. 11, pp. 3458-3463, 2014.

[15] Z. Tian, J. Du, J. Yang et al., "A PCR-RFLP Assay targeting RPS8 gene for the discrimination between bovine Babesia and Theileria species in China," Parasites and Vectors, vol. 8, no. 1, p. 475, 2015.

[16] P. S. Girish, A. S. Anjaneyulu, K. N. Viswas et al., "Polymerase chain reaction-restriction fragment length polymorphism of mitochondrial $12 \mathrm{~S}$ rRNA gene: a simple method for identification of poultry meat species," Veterinary Research Communications, vol. 31, no. 4, pp. 447-455, 2007.

[17] I. Pfeiffer, J. Burger, and B. Brenig, "Diagnostic polymorphisms in the mitochondrial cytochrome $b$ gene allow discrimination between cattle, sheep, goat, roe buck and deer by PCR-RFLP," BMC Genetics, vol. 5, no. 1, p. 30, 2004.

[18] P. Sharma and T. Kobayashi, "Are "universal" DNA primers really universal?," Journal of Applied Genetics, vol. 55, no. 4, pp. 485-496, 2014.

[19] J. Xu, W. Zhao, M. Zhu et al., "Molecular identification of adulteration in mutton based on mitochondrial $16 \mathrm{~S}$ rRNA gene," Mitochondrial DNA, vol. 27, no. 1, pp. 628-632, 2016.

[20] P. Wang, Y. Hu, H. Yang, J. Han, Y. Zhao, and Y. Chen, "DNA-based authentication method for detection of yak (Bos grunniens) in meat products," Journal of AOAC International, vol. 96, no. 1, pp. 142-146, 2013.

[21] R. H. Yin, W. L. Bai, J. M. Wang et al., "Development of an assay for rapid identification of meat from yak and cattle using polymerase chain reaction technique," Meat Science, vol. 83, no. 1, pp. 38-44, 2009.

[22] P. S. Girish, S. Haunshi, S. Vaithiyanathan, R. Rajitha, and C. Ramakrishna, "A rapid method for authentication of Buffalo (Bubalus bubalis) meat by Alkaline Lysis method of DNA extraction and species specific polymerase chain reaction," Journal of Food Science and Technology, vol. 50, no. 1, pp. 141-146, 2013.

[23] B. G. Mane, S. K. Mendiratta, A. K. Tiwari, and K. N. Bhilegaokar, "Detection of adulteration of meat and meat products with buffalo meat employing polymerase chain reaction assay," Food Analytical Methods, vol. 5, no. 2, pp. 296-300, 2011.

[24] M. V. Mahajan, Y. P. Gadekar, V. D. Dighe, R. D. Kokane, and A. S. Bannalikar, "Molecular detection of meat animal species targeting MT 12 S rRNA gene," Meat Science, vol. 88, no. 1, pp. 23-27, 2011.

[25] M. T. Bottero, T. Civera, D. Nucera, and R. M. Turi, "Design of universal primers for the detection of animal tissues in feedstuff," Veterinary Research Communications, vol. 27, no. 1, pp. 667-669, 2003.

[26] T. Kitano, K. Umetsu, W. Tian, and M. Osawa, "Two universal primer sets for species identification among vertebrates," International Journal of Legal Medicine, vol. 121, no. 5, pp. 423-427, 2007.

[27] A. O. Tillmar, B. Dell'Amico, J. Welander, and G. Holmlund, "A universal method for species identification of mammals utilizing next generation sequencing for the analysis of DNA mixtures," PLoS One, vol. 8, no. 12, article e83761, 2013.

[28] F. Ripp, C. F. Krombholz, Y. Liu et al., “All-Food-Seq (AFS): a quantifiable screen for species in biological samples by deep DNA sequencing," BMC Genomics, vol. 15, no. 1, p. 639, 2014.

[29] T. J. Fernandes, J. Costa, M. B. Oliveira, and I. Mafra, "DNA barcoding coupled to HRM analysis as a new and simple tool 
for the authentication of Gadidae fish species," Food Chemistry, vol. 230, pp. 49-57, 2017.

[30] I. R. Maine, R. Atterbury, and K. C. Chang, "Investigation into the animal species contents of popular wet pet foods," Acta Veterinaria Scandinavica, vol. 57, no. 1, pp. 1-4, 2015.

[31] H. Shabani, M. Mehdizadeh, S. M. Mousavi et al., "Halal authenticity of gelatin using species-specific PCR," Food Chemistry, vol. 184, pp. 203-206, 2015.

[32] Q. Wang, X. Zhang, H. Y. Zhang et al., "Identification of 12 animal species meat by T-RFLP on the $12 \mathrm{~S}$ rRNA gene," Meat Science, vol. 85, no. 2, pp. 265-269, 2010.

[33] G. Rastogi, M. S. Dharne, S. Walujkar, A. Kumar, M. S. Patole, and Y. S. Shouche, "Species identification and authentication of tissues of animal origin using mitochondrial and nuclear markers," Meat Science, vol. 76, no. 4, pp. 666-674, 2007.

[34] L. Partis, D. Croan, Z. Guo, R. Clark, T. Coldham, and J. Murby, "Evaluation of a DNA fingerprinting method for determining the species origin of meats," Meat Science, vol. 54, no. 4, pp. 369-376, 2000.

[35] J. F. Montiel-Sosa, E. Ruiz-Pesini, J. Montoya, P. Roncalés, M. J. López-Pérez, and A. Pérez-Martos, "Direct and highly species-specific detection of pork meat and fat in meat products by PCR amplification of mitochondrial DNA," Journal of Agricultural and Food Chemistry, vol. 48, no. 7, pp. 2829-2832, 2000.

[36] I. Martin, T. Garcia, V. Fajardo et al., "Species-specific PCR for the identification of ruminant species in feedstuffs," Meat Science, vol. 75, no. 1, pp. 120-127, 2007.

[37] I. Mafra, I. M. P. L. V. O. Ferreira, and M. B. P. P. Oliveira, "Food authentication by PCR-based methods," European Food Research and Technology, vol. 227, no. 3, pp. 649-665, 2007.

[38] R. L. Patterson and S. J. Jones, "Review of current techniques for the verification of the species origin of meat," Analyst, vol. 115, no. 5, pp. 501-506, 1990.

[39] V. Fajardo, I. González, M. Rojas, T. García, and R. Martín, “A review of current PCR-based methodologies for the authentication of meats from game animal species," Trends in Food Science and Technology, vol. 21, no. 8, pp. 408-421, 2010.

[40] R. Q. Geng, C. Yuan, and Y. L. Chen, "Identification of goat cashmere and sheep wool by PCR-RFLP analysis of mitochondrial 12S rRNA gene," Mitochondrial DNA, vol. 23, no. 6, pp. 466-470, 2012.

[41] S.-Y. Chen, Y.-G. Yao, and Y.-P. Liu, "Species identification of ten common farm animals based on mitochondrial 12S rRNA gene polymorphisms," Animal Biotechnology, vol. 23, no. 3, pp. 213-220, 2012.

[42] H. Y. Feng, C. S. Liu, J. W. He et al., "Identification of mutton from duck meat by PCR-RFLP analysis of mitochondrial DNA cyt b gene," Science and Technology of Food Industry, vol. 33, no. 13, pp. 319-321, 2012.

[43] P. S. Girish, A. S. Anjaneyulu, K. N. Viswas et al., "Meat species identification by polymerase chain reaction-restriction fragment length polymorphism (PCR-RFLP) of mitochondrial 12S rRNA gene," Meat Science, vol. 70, no. 1, pp. 107-112, 2005.

[44] U. K. Hanapi, M. N. Desa, A. Ismail, and S. Mustafa, “A higher sensitivity and efficiency of common primer multiplex PCR assay in identification of meat origin using NADH dehydrogenase subunit 4 gene," Journal of Food Science and Technology, vol. 52, no. 7, pp. 4166-4175, 2015.

[45] M. E. Ali, M. A. Razzak, S. B. Hamid et al., "Multiplex PCR assay for the detection of five meat species forbidden in Islamic foods," Food Chemistry, vol. 177, pp. 214-224, 2015.
[46] N. S. Karabasanavar, S. P. Singh, D. Kumar, and S. N. Shebannavar, "Detection of pork adulteration by highlyspecific PCR assay of mitochondrial D-loop," Food Chemistry, vol. 145, pp. 530-534, 2014.

[47] M. A. Rodriguez, T. Garcia, I. Gonzalez, L. Asensio, P. E. Hernández, and R. Martín, "PCR identification of beef, sheep, goat, and pork in raw and heat-treated meat mixtures," Journal of Food Protection, vol. 67, no. 1, pp. 172-177, 2004.

[48] T. Kitpipit, K. Sittichan, and P. Thanakiatkrai, "Directmultiplex PCR assay for meat species identification in food products," Food Chemistry, vol. 163, pp. 77-82, 2014.

[49] M. Miura, C. Tanigawa, Y. Fujii, and S. Kaneko, "Comparison of six commercially-available DNA polymerases for direct PCR," Revista do Instituto de Medicina Tropical de São Paulo, vol. 55, no. 6, pp. 401-406, 2013. 

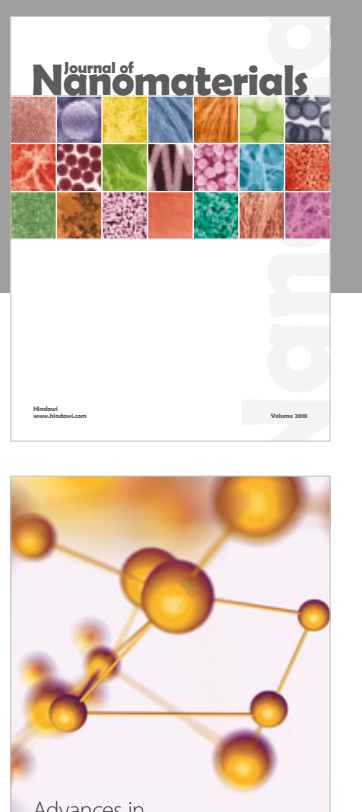

Physical Chemistry
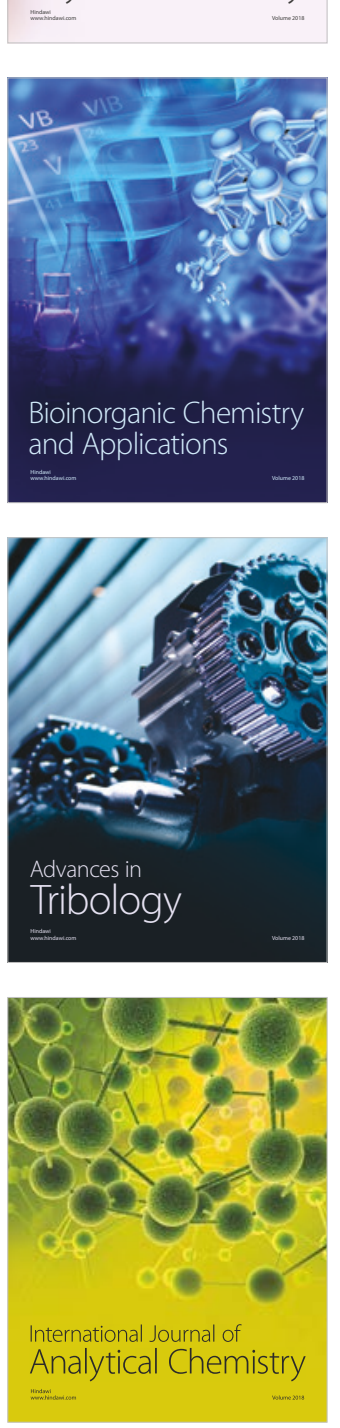

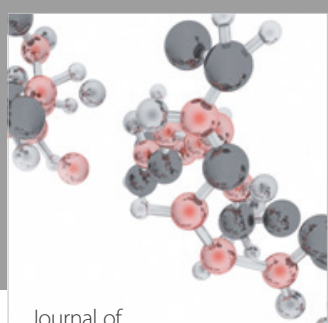

Analytical Methods

in Chemistry

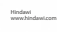

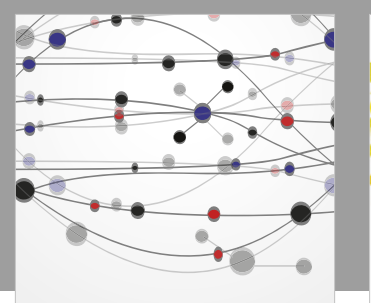

The Scientific World Journal

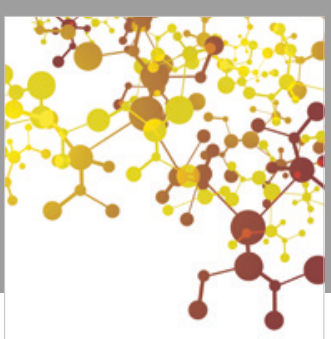

Journal of

Applied Chemistry
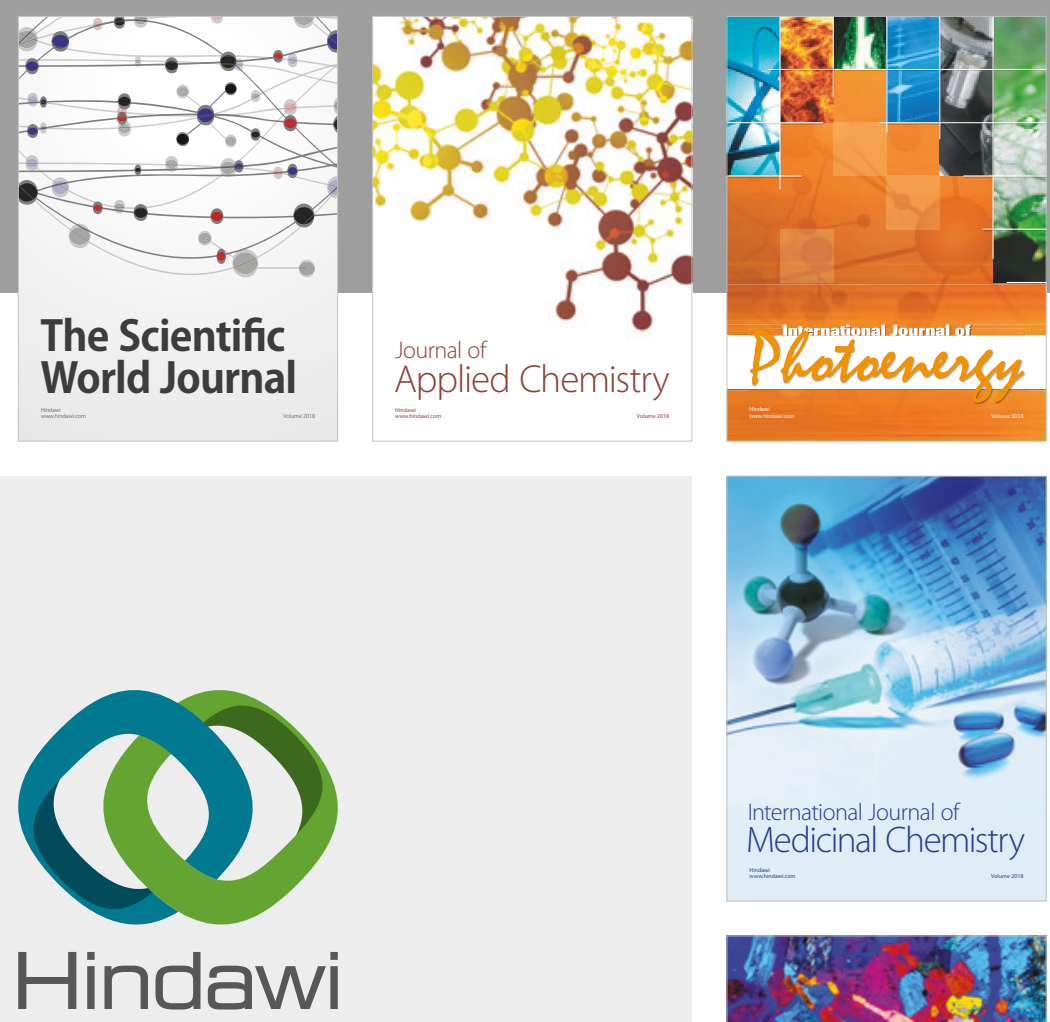

Submit your manuscripts at

www.hindawi.com
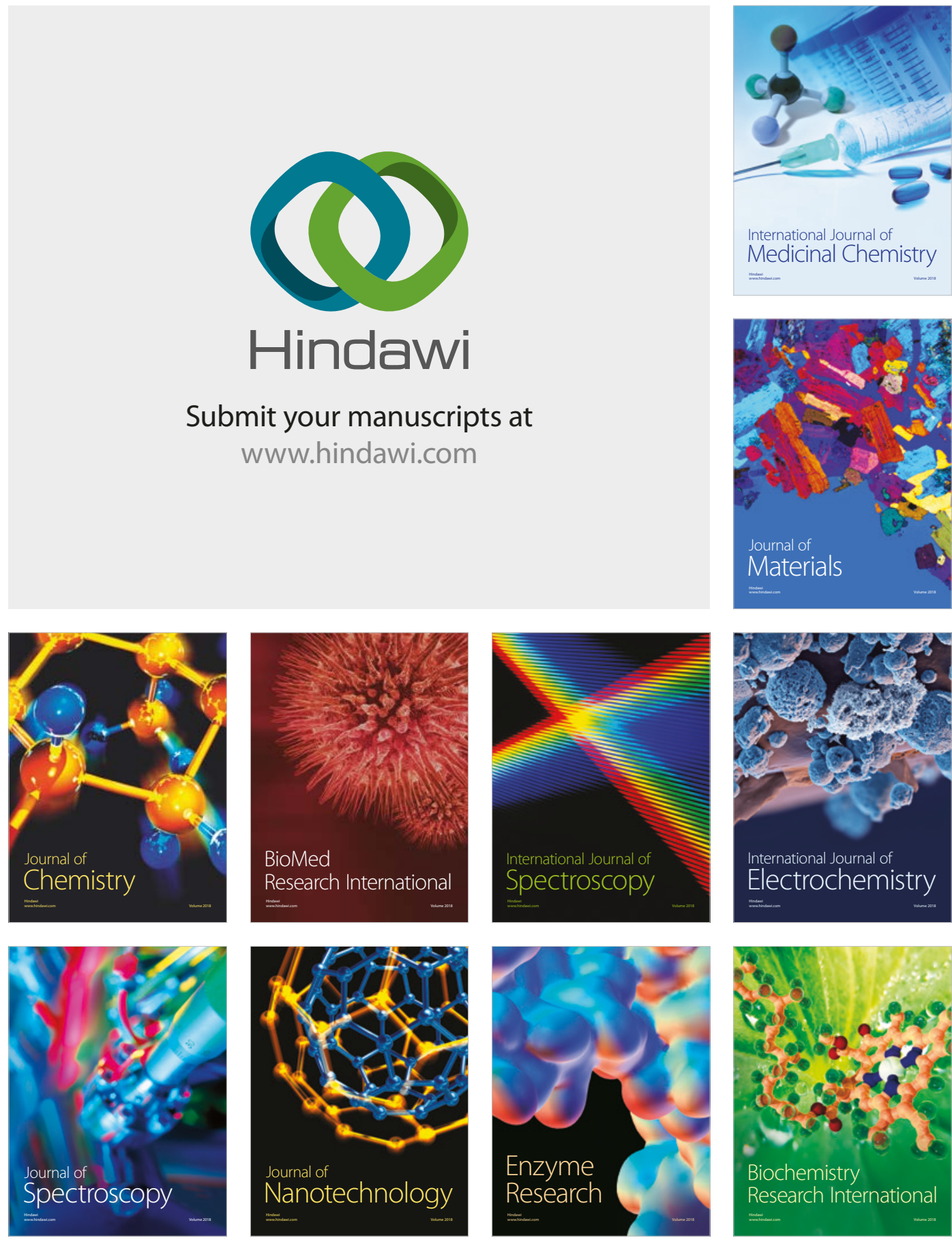
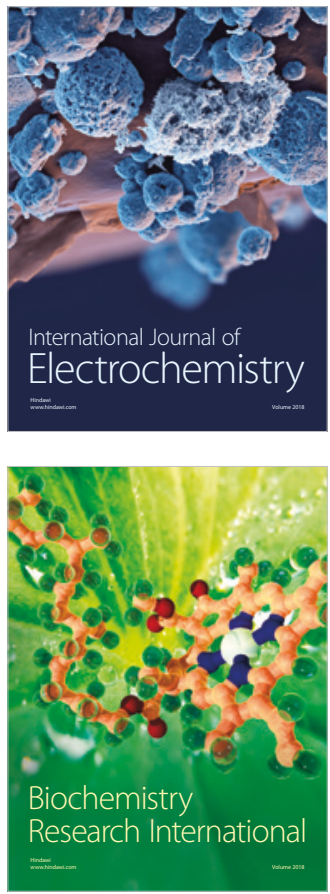